\title{
Predation on Range Sheep with No Predator
}

\section{Control}

\section{J. KENT MCADOO AND DONALD A. KLEBENOW}

Highlight: A Great Basin band of open range herded sheep was monitored intensively for losses between June 8 and September 29, 1976, in an area where organized predator control had not been employed for the preceding 9 years. Verified losses due to all causes totalled $69(4.4 \%$ of the band), of which $59(86 \%)$ were due to predation. Forty-eight of the predator losses were lambs, a $6.3 \%$ loss of the lambs in the herd. Eleven adults were killed by predators.

Ninety percent of the predator losses were attributed to coyotes (Canis latrans), 2\% to bobcats (Lynx rufus), and $8 \%$ to predators of undetermined species. Physical condition was determined for 41 of the sheep attacked by predators: $93 \%$ were healthy and $7 \%$ were in poor condition. Predation intensity varied from approximately one loss every 6 days in June to almost one per day in August and September.

The efficiency of governmentconducted predator control programs in curtailing sheep losses on western ranges has been questioned in recent years by the sheep industry, environmentalists, and the control agencies. Many ranchers feel that toxicants, banned by Executive Order in 1972, were efficient in keeping coyote numbers down and thereby reducing depredations. Current methods which have replaced toxicants are believed by most operators to be much less efficient.

Wagner (1972) questioned the common procedure of evaluating predator control programs by comparing the cost of such programs with the economic loss represented by depredations on livestock (sheep). Inherent in this mode of comparison is the assumption that, without control, predator numbers would be greater and depredations much higher.

Recently, the U.S. Fish and Wildlife Service, responsible for predator control in many western states, has conducted several studies to determine the extent of predation in areas without control. Research was conducted on a Montana ranch in 1974 (Henne 1975) and 1975 (Munoz 1976), and on a New Mexico ranch in 1974 and 1975

Authors are research associate and associate professor, Division of Renewable Natural Resources, University of Nevada, Reno.

This report is a contribution of the U.S. Fish and Wildlife Service, Contract No. 14-16-0008-2051, and the Nevada Agricultural Experiment Station, Journal Series No. 364 .

Manuscript received May 21, 1977
(DeLorenzo and Howard 1976). These studies reported much higher losses than are apparently typical of most western range operations (Presnall 1948; Nielson and Curle 1970; Reynolds and Gustad 1971; Early et al. 1974a and b; Magleby 1975; Klebenow and McAdoo 1976). However, results could have been influenced by variables other than the lack of predator control. In the Montana and New Mexico studies, sheep were grazed in large fenced pastures, unherded. Nearly half of the sheep in the West are grazed on open range (Gee and Magleby 1976), and usually watched by herders.

Although no control was the goal during the Montana and New Mexico studies, it probably was not achieved in either case. Predator control was employed in both of the Montana studies during the 5-month period after lambs were shipped. No control was employed during the New Mexico study, but adjacent ranches intensified control efforts, and the researchers believed this may have influenced results.

With these problems in mind, the operation chosen for this study was one in which sheep were herded on open range, and in an area where predator control had not been conducted by government agencies for the preceding 9 years. According to George Roberts, the rancher whose sheep we studied, little or no commercial trapping occurs on his summer range (the study area).

Since the rancher cooperated by branding a separate bunch of sheep for research purposes and agreed to herd these sheep in a manner "typical" of sheep operations in the Great Basin area, he was reimbursed by the Fish and Wildlife Service for all verified predator losses. The study began shortly after the sheep arrived on summer range (June 8, 1976), and was terminated when market lambs were separated out to be fattened on alfalfa (September 29, 1976).

\section{Study Area and Sheep Management}

The area on which the study band ranged was located on the west slope of the Sweetwater Mountains (about $32 \mathrm{~km}$ northwest of Bridgeport, California, and $14 \mathrm{~km}$ southwest of the Nevada State line), on the Bridgeport District of the Toiyabe National Forest. Elevation on this 5,700-ha area varied from 2,100 to $3,000 \mathrm{~m}$.

The area was dominated by northern desert shrub, mountain brush, and pine forest type vegetation. Big sagebrush (Artemisia tridentata), bitterbrush (Purshia tridentata), snowberry (Symphoricarpus spp.), and serviceberry (Amelanchier alnifolia) were the common shrubs in the area. Grasses and forbs included bluebunch wheatgrass (Agropyron spicatum), bottlebrush squirreltail (Sitanion hystrix), bluegrass (Poa spp.), lupine (Lupinus spp.), and arrowleaf balsamroot (Balsamhoriza sagittata).

Mountain mahogany (Cercocarpus ledifolius) occurred in stands along some ridge tops. In addition, groves of aspen (Populus tremuloides) and patches of willow (Salix spp.) were common along stream bottoms and adjacent slopes. Stands of lodgepole pine (Pinus contorta) occurred at higher elevations, primarily on north slopes.

Terrain varied from gently rolling hills and almost flat terraces, to very steeply sloping canyons. Three small streams flowed through the area.

The climate is characterized by long, cold winters and warm, dry summers. Annual precipitation, primarily in the form of snow, falls mostly during the winter and spring.

The initial study band consisted of 238 
ewes and 312 lambs (550 shecp total). Although such a small band is not typical of western range operations, original intent was to keep the flock small in order to facilitate reimbursement of the rancher in the event that predator losses should skyrocket under the "no control" study conditions. However, on July 28, 1976, the study band and another band from the same operation mixed, resulting in a band consisting of approximately 1,240 ewes and 1,125 lambs $(2,365$ sheep total $)$. Since losses had been minimal to this point, a decision was made to study this larger band of more representative size, rather than attempt to separate out the original band.

Throughout the study period, the sheep were open-herded as recommended by the U.S. Forest Service. The herder was requested to bed the sheep as is typical of western range operations. Also, propane "cannons" used by other herders in this operation to avert coyotes were considered nontypical, and were not used near the study band. However, the herder did carry a rifle and pistol, and shot at predators, since this practice is typical of most western operations.

\section{Methods}

Research personnel made at least two searches daily for carcasses, wounded animals, and lost or strayed sheep. An investigator accompanied the herder at dawn each morning as the sheep were moved off bedding areas. These bedding grounds and surrounding vicinities were checked thoroughly for losses by making several transects afoot and glassing all open areas. Dogs were also used successfully for searching out losses in heavy cover.

Day-use areas (where sheep grazed, watered, and rested) were routinely checked each afternoon in conjunction with moving the sheep toward bedding areas. Areas of dense vegetation were often rechecked at mid-day (when shadows are few) for possible losses overlooked earlier.

Strays and incapacitated animals were located by making trips into areas previous!y occupied by sheep. In addition, the periphery of the band was checked daily for the slower moving wounded, crippled, or diseased animals.

After a carcass was located, the objective was to determine whether the animal had been attacked and killed by a predator, or had died from other causes. Techniques for verifying causes of death have been described by Rowley (1969, 1970), Wiley and Bolen (1971), Bowns et al. (1973), and McAdoo (1975). Primarily, the presence or absence of puncture wounds, in conjunction with subcutaneous hemorrhages, free blood, and bloodstains were the bases for differentiating between predator-caused losses and other losses.

Nondcath losses included strays and wounded animals. Only those strays which were permanently abandoned were re- corded. Since buyers will not accept animals which have survived attacks by predators, animals so wounded were also recorded as losses. Most of these animals apparently die eventually from shock, infection, or biological stress (Bowns 1976).

Wounds, types of consumption patterns, tracks, droppings, sightings of predators in the area, and other kill-site evidence were used to determine the predator species involved in each attack on sheep. Predator identification has been discussed by Rosko (1948), Gier (1957), Rowley (1969), Bowns et al. (1973), and McAdoo (1975).

Victims of predator attacks were examined for any external abnormalities (swollen joints, broken bones, general emaciation, etc.). Lacking any external evidence of a weak condition, the health of a lamb was judged by its relative size compared to other lambs at that time.

Two major (corral) counts of sheep, when the bands were organized at shearing time (Junc 8, 1976), and again when the market lambs were separated out (September 29, 1976), permitted a comparison between verified and actual losses. Also, during the period when the small band was being studied (June 8-July 27), four accurate field counts were made. After mixing with the other band, the resulting larger band did not easily lend itself to field counts.

\section{Results}

A total of 69 losses (due to all causes) was verified. Fifty-nine $(86 \%)$ were due to predation, and ten (14\%) to miscellaneous causes (Table 1). Miscellaneous losses included two old ewes which died of undetermined natural causes, five lambs which died from disease, and three stray sheep (2 ewes, 1 lamb). The 59 predator losses included eight lambs which were wounded but not killed outright. One of these was taken to the ranch for treatment and died within 3 days. Four apparently died within 2 days of observation since they were never

\section{Table 1. Domestic sheep losses (no.) and predation intensity verified from a Great Basin range band during the summer of 1976 .}

\begin{tabular}{|c|c|c|c|c|c|c|c|c|}
\hline \multirow[b]{3}{*}{ Time period } & \multirow{3}{*}{$\begin{array}{l}\text { Length } \\
\text { of period } \\
\text { (days) }\end{array}$} & \multicolumn{6}{|c|}{ Verified losses } & \multirow{3}{*}{$\begin{array}{c}\text { Predation } \\
\text { intensity } \\
\text { (1 loss/ } \\
\text { no. days) }\end{array}$} \\
\hline & & \multicolumn{2}{|c|}{ Predation } & \multicolumn{2}{|c|}{ Misccllaneous } & \multicolumn{2}{|c|}{ Totals } & \\
\hline & & Ewes & Lambs & Ewes & Lambs & Ewes & Lambs & \\
\hline $\begin{array}{l}\text { June } \\
(6 / 8-6 / 30) \\
\text { July }\end{array}$ & 23 & - & 4 & - & 2 & 0 & 6 & $1 / 6$ \\
\hline$(7 / 1-7 / 31)$ & 31 & - & 6 & 1 & 1 & 1 & 7 & $1 / 5$ \\
\hline $\begin{array}{l}\text { August } \\
(8 / 1-8 / 31)\end{array}$ & 31 & 5 & 20 & 1 & 1 & 6 & 21 & $1 / 1$ \\
\hline $\begin{array}{l}\text { September } \\
(9 / 1-9 / 28)\end{array}$ & 28 & 6 & 18 & 2 & 2 & 8 & 20 & $1 / 1$ \\
\hline Totals & 113 & 11 & 48 & 4 & 6 & 15 & 54 & 1/2 (Avg.) \\
\hline \multicolumn{2}{|c|}{ Total ewes plus lambs } & \multicolumn{2}{|c|}{$59(86 \%)$} & \multicolumn{2}{|c|}{$10(14 \%)$} & \multicolumn{2}{|c|}{$69(100 \%)$} & \\
\hline
\end{tabular}

again observed in the band. The other three were wounded later in the study and were considered to have died eventually.

The determination of the predation rate was complicated by the quadrupling of band size which resulted when the original study band mixed with another in late July. Before mixing, $1.6 \%$ of the original band was lost to predators; and after mixing, $2.1 \%$ of the newly formed band fell prey. Based on the average size of the band for the study duration, an ovcrall predation rate of $3.8 \%$ was incurred, and $0.6 \%$ of the band was lost to miscellaneous causes (Table 1). Predators killed 6.3\% of the lambs.

The mixing of the initial study band with another band also complicated the determination of verification success. The last count made of the small band (one week before mixing occurred) indicated that $100 \%$ of all losses to this time had been accounted for. The next count obtained was the count of the larger mixed band at termination of study (September 29).

Early summer counts obtained at shearing were available for both the initial study band and the band with which it was later mixed. Therefore, it was possible to compare the number of verified losses for the composite band which occurred after mixing to the number of losses bascd on counts. However, the final count at shipping indicated that 53 more losses were verified than the counts indicated. Apparently, an incorrect count at shearing of the band with which the initial study band eventually mixed was the cause of this discrepancy. Because of this counting error, verification success could not be accurately determined. We believe we found most of 
the dead sheep, possibly even $100 \%$ of the losses.

Predation intensity, a measure of predation frequency based on verified losses, has been expressed as one predator loss per $X$ number of days (Table 1). Predator losses varied from approximately one loss in 6 days during June, to one loss in 5 days for July, to almost one loss per day in August and September. During the entire study, the band incurred an average predation intensity of nearly one loss every 2 days.

Of the 59 predator losses verified, 53 $(90 \%)$ were attributed to coyotes (Canis latrans), $1(2 \%)$ to a bobcat (Lynx rufus), and 5 (8\%) to predators of undetermined species (Table 2). Black bears (Ursus americanus) and mountain lions (Felis concolor) were present in the study area, but no depredations by these species were verified.

Table 2. Verified sheep losses (from a Great Basin range band) attributed to different predators during the summer of 1976.

\begin{tabular}{lcc}
\hline & \multicolumn{2}{c}{ Sheep losses } \\
\cline { 2 - 3 } Predator & Number & \% of total \\
\hline Coyote & 53 & 90 \\
Bobcat & 1 & 2 \\
Bear & 0 & 0 \\
Lion & 0 & 0 \\
Undetermined & 5 & 8 \\
\hline
\end{tabular}

Table 3 lists the estimated physical condition of 41 sheep which were attacked by predators. Thirty-eight $(93 \%)$ of these sheep were classified as healthy; three $(7 \%)$ were in poor condition. Two of these were relatively small lambs attacked in July, and the other was a large wether which had been observed previously limping and lagging behind with a swollen front leg joint. The physical condition for 18 losses was considered nonassessable. These sheep had been consumed to such an extent by predators and/or scavengers that accurate assessments were not possible.

\section{Discussion}

Predation was the major cause of

Table 3. Physical condition of 41 predator losses verified from a Great Basin range sheep band during the summer of 1976 .

\begin{tabular}{lcc}
\hline & \multicolumn{2}{c}{ Losses } \\
\cline { 3 - 3 } Condition of sheep & Number & $\%$ of total \\
\hline Healthy & 38 & 93 \\
Poor & 3 & 7 \\
\hline
\end{tabular}

sheep losses during the study. Several studies have shown predation on westem ranges to be the primary cause of summer sheep deaths (Bowns et al. 1973; Early et al. 1974a and b; Henne 1975; Klebenow and McAdoo 1976; Munoz 1976). Generally speaking, sheep are in good physical condition during the summer period, and except for instances when herders lose many strays, predation can be expected to be the major cause of loss during this time.

The $3.8 \%$ predation rate on the total herd and $6.3 \%$ loss of lambs to predators in our Great Basin study are much lower than those reported during "no control" studies in New Mexico and Montana. DeLorenzo and Howard (1976) reported $15.6 \%$ and $12.1 \%$ losses of lamb crops to predators in two consecutive years in New Mexico. Henne (1975) reported that predators killed $29.3 \%$ of the lamb crop on a Montana ranch during 1974, and the following year Munoz (1976) reported a loss of similar magnitude (24.4\%) on the same ranch. More than $16 \%$ of the total flock was killed each year during these two studies.

The relatively short duration of our study (compared to the abovementioned studies) may partly account for the difference in results. If the equivalent 4-month time periods (June through September) are considered for each of the above studies, a more valid comparison can be made. From data reported by DeLorenzo and Howard (1976), we calculated lamb losses (to predators) of $8.8 \%$ and $5.6 \%$ for the summers of 1974 and 1975, respectively, in their New Mexico study. Similar calculations, using data reported by Henne (1975) and Munoz (1976), showed summer predation rates on lambs of about 14\% and 13\% (in 1974 and 1975, respectively), during their studies in Montana. Except for the 1975 summer period of the New Mexico study, these loss rates are all higher than the $6.3 \%$ loss of lambs to predators during our "no control" study.

When an analysis of each of the "no control" studies is made, the obvious difference between ours and the others is that of sheep management. During our study, sheep were herded daily by a herder, to and from grazing, watering, salting, and bedding areas. This is typical of many large operations which graze sheep on public lands in the Great Basin. The other studies involved sheep being grazed "unherded" within large fenced pastures on private land. Perhaps the presence of a herder as he moves the sheep with dogs twice daily, shouting and whistling, shooting at predators sighted, often staying with the sheep for several hours at a time, is in itself a deterrent to predation.

Other factors, such as predator density, natural prey density and/or availability, could also be partially responsible for the differences in predation rates between each of the "no control" studies. However, these parameters were not measured and no valid comparisons can be made.

Attempts were made during the study to simulate herding as is practiced commonly in the Great Basin. However, in the process of encouraging the herder not to use his propane cannon or bring his sheep to camp each night, he may have derived the idea that his band should be essentially ignored at night. On 28 occasions (during August and September), his sheep were bedded in multiple ( 2 to 5 ) bunches, 0.5 to $2.5 \mathrm{~km}$ apart (Table 4). Twenty-nine sheep were attacked by coyotes during these multiple bunch nights.

\begin{tabular}{|c|c|c|c|}
\hline $\begin{array}{l}\text { Number of } \\
\text { bunches }\end{array}$ & $\begin{array}{c}\text { Number } \\
\text { of } \\
\text { nights }\end{array}$ & $\begin{array}{c}\text { Number } \\
\text { of } \\
\text { kills }\end{array}$ & $\begin{array}{c}\text { Number of } \\
\text { kills/ } \\
\text { night }\end{array}$ \\
\hline Multiple (2-5) & 28 & 29 & 1.04 \\
\hline One & 30 & 20 & 0.67 \\
\hline
\end{tabular}

This is an average of 1.04 sheep killed per night, compared to 0.67 sheep killed per night during the one-bunch nights of these same months. Apparently, leaving the sheep bedded in more than one group at night increased cxposurc to predators and thus increased predator losses. Peripheral bunches received little or no protection afforded by the herder and his dogs.

Herd size was determined by computing the average size of the band during the study, since the original bunch mixed with another during late July. The question arises: Which is more vulnerable to predation, a small band or a large one? Perhaps no conclusive answer can be given. However, in light of observations made during the study, we believe that a relatively small band in a given area may suffer a number of predator losses 
similar to a larger band in the same area, though predation rate for the small band would be greater. During the period before the herds mixed, our small band (550 head) incurred nine predator losses, compared to six losses observed by the herder for the larger band $(1,815$ head) with which we mixed. However, the herder was using a propane cannon at this time and no doubt herding more intensively, complicating the comparison.

The late summer predation increase observed in our study has also been reported by several researchers on other western ranges (Rosko 1948; Bowns et al. 1973; Klebenow and McAdoo 1976; Terry Rock personal communication, Saskatchewan Dep. of Natural Resources, Saskatoon). This increase was forecasted by ranchers and herders. Carcasses of predator losses verified in late summer were utilized to a greater extent by coyotes than those found earlier in the summer, and were fed on extensively by pups (judging by tracks and feces near kills). The growing pups are more active in late summer, and we believe that the resultant increased food requirement is a cause of the peak in predation intensity at this time of year.

The majority of sheep attacked by predators were healthy. Henne (1975), Klebenow and McAdoo (1976), and Munoz (1976) reported similar findings. Domestication has bred out natu$\mathrm{ral}$ defense and/or escape mechanisms in sheep (Kupper 1945; Howard 1974). There is no reason to believe that predators are forced to select unfit individuals among an introduced species which, even when healthy, are highly susceptible as prey. Since coyotes are attracted by movement of prey (Fox 1971), more active, healthier animals can be expected to be attacked most often. Field observations of coyotes chasing sheep (Henne 1975; McAdoo 1975) indicated that coyotes tend to pursue a fast-moving animal which breaks away from the herd.

We believe that our study area came as close to being free from the influence of predator control as is possible for an area of sheep-grazed public land. The nearest government control took place during winter and spring in valleys approximately 30 to $60 \mathrm{~km}$ from the study area, and consisted primarily of intensive aerial shooting and some trapping. Commercial trapping was apparently negligible on the study area, and was probably inconsequential (though unmeasured) in the outlying vicinities of lower elevations.

\section{Literature Cited}

Bowns, J. E., J. W. Davenport, J. P. Workman, D. B. Nielson, and D. D. Dwyer. 1973. Determination of cause and magnitude of sheep losses in southwestern Utah. Utah Sci. 34(2):35-37, 52.

Bowns, J. E. 1976. Field criteria for predator damage assessment. Utah Sci. 37:26-30.

DeLorenzo, D. G., and V. W. Howard, Jr. 1976. Evaluation of sheep losses on a range lambing operation without predator control in southeastern New Mexico. Final Rep. to the U.S. Fish and Wildl. Serv., Denver Res. Center. New Mexico State Univ., Las Cruces. $34 \mathrm{p}$.

Early, O. E., J. C. Roetheli, and G. R. Brewer. 1974a. An economic study of predation in the Idaho range sheep industry, 197071 production cycle. Idaho Agr. Res. Prog. Rep. No. 182. 49 p

Early, O. E., J. C. Roetheli, and G. R. Brewer. 1974b. An economic study of predation in the Idaho range sheep industry, 1972 73. Idaho Agr. Res. Prog. Rep. No. 186. 46 p.

Fox, M. W. 1971. Behavior of Wolves, Dogs, and Related Canids. Harper and Row, New York. 220 p.

Gee, K., and R. Magleby. 1976. Characteristics of sheep production in the western United States. U.S. Dep. Agr. Econ. Res. Serv. Agr. Econ. Rep. No. 345.47 p.
Gier, H. T. 1957. Coyotes in Kansas. Kansas State Univ. Agr. Exp. Sta. Bull. 343. 97 p.

Henne, D. R. 1975. Domestic sheep mortality on a western Montana ranch. MS Thesis. Univ. of Montana, Missoula. 53 p.

Howard, W. E. 1974. The biology of predator control. Addison-Wesley Modules in Biology No. 11. Addison-Wesley Publ. Co., Inc., Reading, Mass. 48 p.

Klebenow, D. A., and K. McAdoo. 1976. Predation on domestic sheep in northeastern Nevada. J. Range Manage. 29:96-100.

Kupper, W. 1945. The golden hoof. Alfred A. Knopf, New York. 343 p.

Magleby, R. S. 1975. Sheep losses due to predators and other causes in the western United States, 1974. U.S. Dep. Agr. Econ. Res. Serv. Prelim. Rep. No. 616. 4 p.

McAdoo, K. 1975. Predation on domestic sheep in northeastern Nevada. MS Thesis. Univ. of Nevada, Reno. $106 \mathrm{p}$.

Munoz, J. R. 1976. Causes of sheep mortality at the Cook Ranch, Florence, Montana, 1975-76. Annual Rep. to U.S. Fish and Wildl. Serv., Denver Res. Center. Contract No. 14-160008-1135. 44 p.

Nielson, D. B., and D. Curle. 1970. Predator costs to Utah's range sheep industry. Nat. Woolgrower. 60:14-22.

Presnall, C. C. 1948. Applied ecology of predation on livestock ranges. J. Mammal. 29:155-161.

Reynolds, R. N., and O. C. Gustad. 1971. Analysis of statistical data on sheep losses caused by predation in four western states during 1966-69. U.S. Bur. Sport Fish. and Wildl., Div. Wildl. Serv. Rep. 21 p.

Rosko, L. 1948. Losses of sheep from predatory animals on summer ranges in Iron County, Utah. Utah Coop. Wildl. Res. Unit Rep. 16 p.

Rowley, I. 1969. An evaluation of predation by "crows" on young lambs. Common. Sci. and Ind. Res. Organ., Aust., Wildl. Res. 14: 153-179.

Rowley, I. 1970. Lamb predation in Australia: Incidence, predisposing conditions, and the identification of wounds. Common. Sci. and Ind. Res. Organ., Aust., Wildl. Res. 15: 79-123.

Wagner, F. H. 1972. Coyotes and sheep: Some thoughts on ecology, economics, and ethics. 44th Utah State Univ. Faculty Honor Lect. $59 \mathrm{p}$.

Wiley, R. W., and E. G. Bolen. 1971. Eaglelivestock relationships: Livestock carcass and wound characteristics. Southwestern Natur. 16:151-169. 